\title{
ENTREPRENEURS IN CRAFT BEER AND TOURISM: PERSPECTIVES FROM SOUTH AFRICA
}

\author{
Christian M. ROGERSON* \\ School of Tourism \& Hospitality, College of Business and Economics, University \\ of Johannesburg, Johannesburg (South Africa), email: crogerson@uj.ac.za \\ Keagan J.E. COLLINS \\ School of Tourism \& Hospitality, College of Business and Economics, University \\ of Johannesburg, Johannesburg (South Africa). email: Collinsk.j.e.@gmail.com
}

\begin{abstract}
Citation: Rogerson, C.M. \& Collins, K.J.E. (2019). ENTREPRENEURS IN CRAFT BEER AND TOURISM: PERSPECTIVES FROM SOUTH AFRICA. GeoJournal of Tourism and Geosites, 27(4), 1158-1172. https://doi.org/10.30892/gtg.27404-423
\end{abstract}

\begin{abstract}
Beer tourism attracts a growing international scholarship. As a result of the craft beer revolution a marked shift in beer tourism research is noticeable. The major focus is on the producers of specifically craft beer, of visits to craft beer micro-breweries and the evolution of craft beer trails. Existing scholarship on beer tourism and craft beer entrepreneurship is concentrated mainly in the global North. This article examines the appearance, motivations and challenges of entrepreneurs in craft beer in South Africa, a destination strongly associated with wine tourism but one that is increasingly developing an economy of craft beer tourism. The appearance of craft beer production is positioned within theoretical debates about resource-partitioning and craft beer entrepreneurship emphasizing the importance of passion as motivation. The results of qualitative responses from 53 craft brewery micro-entrepreneurs in South Africa show distinct parallels with research findings reported from the global North about the passion that drives the growth of the entrepreneurs building the craft beer industry.
\end{abstract}

Key words: beer tourism; craft beer; beer entrepreneurs; business motivations and challenges; South Africa

\section{INTRODUCTION}

Over the past two decades a close relationship has consolidated between the international growth of beer tourism and of the development of entrepreneurship in the production of craft beer. The niche of beer tourism represents an extension of gastronomic or culinary tourism (Niester, 2008; Bujdoso \& Szucs, 2012a; Murray \& Kline, 2015). It is a form of tourism in which participants' motivations centre on the experience of drinking different types of beer, the typical environment of brewpubs and restaurants, or learning

\footnotetext{
* Corresponding author
} 
about brewing history and of beer production (Jablonska et al., 2013). According to Bujdoso \& Szucs (2012b: 105) "beer tourism has become a new and popular form of alternative tourism" as well as "a growing industry as more and more companies offer tours to beer brewing regions". Brewery-based tourism is a means for destinations to attract tourists either as the main attraction or as a supplementary tourism product (Howlett, 2013). Global scholarship on beer tourism encompasses several different issues such as the characteristics of beer tourists; the organization of beer tourism through visits to breweries, beer museums and exhibits; the development of beer festivals and ale trails; and, the local development impacts of beer tourism for destinations (see e.g. Lyons \& Sharples, 2008; Pechlaner et al., 2009; Alonso, 2011; Bujdoso \& Szucs, 2012a, 2012b; Kraftchick et al., 2014; Murray \& Kline, 2015; Rogerson \& Collins, 2015a, 2015b, 2015c; Csapo \& Wetzl, 2016).

Overall, what is observed most notably about the recent trajectory of beer tourism research across Australasia, much of Europe and especially of North America is a concentrated focus upon the producers of specifically craft beer, of visits to craft beer micro-breweries and the evolution of craft beer trails (Plummer et al., 2005; Francioni, 2012; Slocum, 2016; Alonso \& Sakellarios, 2017; Alonso et al., 2017; Kline et al., 2017; Argent, 2018; Slocum et al., 2018; McMullin et al., 2019). As Garavaglia \& Swinnen (2017a: 1) aver "craft brewers and their customers have transformed global beer markets over the past two decades, ending a century of consolidation that resulted in the domination of a few global multinationals and the homogenization of beer". Internationally, the growing domination of increasingly standardized lager and light beers, which were manufactured by progressively fewer brewing enterprises, precipitated a counter movement against consolidation and the lack of beer variety (Poelmans \& Swinnen, 2011). Mass production caused standardization of beer to the point where consumers often could not discern taste differences between the more generic mass market pale lagers (Campbell \& Goldstein, 2010). The result has been the international 'craft beer revolution' as an increasing cohort of beer consumers began to show renewed interest in drinking 'older' styles such as pale ales, porter, and stout (Patterson \& Hoalst-Pullen, 2014). By contrast to the homogeneous character of lager brews produced by multinationals and macrobrewers "the output of the craft segment more closely resembles the product differentiation and fragmentation in the wine industry" (Elzinga et al., 2015: 242).

The international diffusion of this beer revolution has been uneven geographically. For the USA Elzinga et al. (2015) identify 1965 as the starting point. In the United Kingdom it is associated with the emergence during the 1970s of the Campaign for Real Ale (Maye, 2012; Danson et al., 2015; Garavaglia \& Swinnen, 2017b). Murray \& O’Neill (2012: 899) state that craft beers "have been steadily gaining market share from the large national and international beer breweries". The gradual advance of craft beer production has been a global trend and is accompanied by the growth in the number of micro- and craft breweries (Patterson \& Hoalst-Pullen, 2014; Cabras \& Higgins, 2016; Garavaglia \& Swinnen, 2017b). Toro-Gonzalez (2015: 1) identifies current market conditions in Latin America as favourable for the significant growth of the region's brewing industry and "particularly for craft and speciality beers". Indeed, across much of the world the beer industry has undergone a radical 'makeover' in terms of both landscapes of production and consumption. For example, in the USA demand for craft brews has (re) invented beer as a serious consumption good to be paired with food, rather than simply as a liquid that quenched thirst on a hot day or offered an inexpensive buzz (Elzinga et al., 2015: 248).

Chapman (2015: 102) asserts that the formerly monolithic world of beer has been transformed by a new beer culture distinguished by "variety, diversity, ingenuity, creativity and unbridled excitement". It is observed that the culture, economy and landscape of beer has been "turned upside down in a fruitful quest for new beer 
paradigms" (Chapman, 2015: 102). In terms of the changing focus of beer tourism the appearance of craft breweries forged new opportunities for tourists "to visit small breweries to learn about, sample and buy craft beer and meet the brewers" (Dunn \& Kregor, 2014: 190). Craft beer is viewed an 'experience-based' and symbolic product with its consumption motivated variously by the desire to move away from mainstream homogenous beer consumption, a search for new taste experiences and for new knowledge about beer (Kraftchick et al., 2014; Gomez-Corona et al., 2016; Kline et al., 2017). Moreover, in common with other premium niche culinary tourism sectors such as wine or whisky, Dunn \& Wickham (2016: 140) note that "craft breweries have the ability to offer premium quality experiential services as part of their product offering".

Existing scholarship on beer tourism and entrepreneurship in craft beer mostly is concentrated upon the global North (Kline et al., 2017; Slocum et al., 2018). Against this backcloth, the aim in this paper is to examine the appearance, characteristics and challenges of craft beer entrepreneurs in South Africa, a destination strongly associated with wine tourism but one that is increasingly developing an economy of craft beer tourism (Rogerson \& Collins, 2015a, 2015b; Rogerson, 2016). Within sub-Saharan Africa South Africa is the most advanced country in terms of the growth of a craft beer industry and of the emergence of craft beer tourism. The analysis of craft beer entrepreneurship in South Africa unfolds through two further sections of discussion. The next section situates the appearance of craft beer production within international theoretical currents about resource-partitioning theory and around craft beer entrepreneurship. Attention then moves to the South African case and the results of an investigation concerning the nature, motivations and challenges of the community of craft beer entrepreneurs.

\section{THEORETICAL CONTEXT}

Several explanations are offered to account for the growth of craft brewing in an era of globalization and mass production. At the most basic level explanations for the rise of craft beer in the United States often focus on the agency and pioneering activities of successful brewers or the efforts of several home-brewers turned entrepreneurs (Chapman, 2015). Other observers centre more on themes of industry structure in brewing and of how high levels of concentration and the dominance of a small number of firms resulted in an unmet need that craft beer was able to fulfil (Tremblay et al., 2005; Garavaglia \& Swinnen, 2017a, 2017b). Further debate surrounds the structure of organizations in the brewing industry and suggests that larger firms are less well equipped than smaller micro-breweries to address changing consumer preferences and cultural tastes (Chapman, 2015; Garavaglia \& Swinnen, 2017a). The overall argument, as summarised by Herrera (2016: 16), is that in a highly price competitive industry such as beer production 'generalist firms' once aimed to capture the largest amount of consumers which "opened the door for small, craft firms to enter the marketplace and target narrow segments of the consumer base through a variety of highly specialized products".

Resource partitioning theory is at the heart of vibrant theoretical debates (Carroll et al., 2002; Liu \& Wezel, 2015). Esposti et al. (2017: 504) assert that scholarship around resource-partitioning "is one of the major contributions explaining the emergence of multiple segments within a maturing industry". For the brewing industry the seminal work is that by Carroll \& Swaminathan (2000). According to the logic of many theories of organization, the dominance of large firms in an industry should constrain the emergence and operations of small specialist enterprises (Carroll et al., 2002). Resource partitioning theory challenges this notion by showing the existence of several maturing industries in modern economies that exhibit simultaneous trends of increased concentration and specialist proliferation. These dual trends are viewed interdependent as the theory holds 
that under certain organizational and market conditions the increased dominance of large firms in an industry enhances the opportunities for specialist organisations (Carroll et al., 2002). When industries become highly centralised in monopolistic or oligopolistic arrangements large industry players are regarded as 'generalists' and open up opportunities for small firms to enter the market as 'specialists'. As argued by Carroll \& Swaminathan (2000: 717) a resource partitioning model "explains the rise of late-stage specialist segments within an industry as an (unexpected) outcome of the consolidation occurring among large generalist organisations as they compete for the largest consumer resource bases of the mass market". Adoption of a massification strategy by generalist organisations thus increases the opportunities for specialist organisations and "small specialist producers exploit the opportunities for more specialised products" (Garavaglia, 2015: 11).

As applied to the brewing sector by Carroll \& Swaminathan (2000) the above analysis has come under critical scrutiny and elaboration. Indeed, for Garavaglia (2015: 11) "this explanation is too simplistic". That said, Carroll \& Swaminathan (2000) identify also the role of cultural factors. It is argued that "anti-mass production feelings, which follow concerns about scale, lead consumers to seek out specialist producers, wherein they make assumptions about quality and authenticity, even when the objective quality of generalist-produced products might be higher, or at least more consistent" (Pozner et al., 2015: 8). Accordingly, by choosing specialist rather than mainstream goods such consumers "may be enacting a symbolic protest against mass-produced society and corporate organizations" (Pozner et al., 2015: 8). In the case of Italy Garavaglia (2015) places greater emphasis upon demand-side issues. Factors discussed are consumer attitudes and changes in terms of demand which is becoming more sophisticated, refined and inclined to greater variety. In turn this shift of consumer behaviour opens up spaces for new businesses and organisational forms in brewing such as for craft beer micro-breweries. New cultural meanings also are attributed to consumption choices such that, as post-modern writers emphasise, "consumers were no longer just consumers"; rather "consumption was not only for utility but also for experience" (Garavaglia, 2015: 15). Indeed, as a whole, small producers are more likely than larger homogeneous 'generalist' organisations to customise their offerings to the particular needs of customer niches and of emerging micro-segments (Pozner et al., 2015: 9).

In terms of specific in-depth research on micro-entrepreneurs of craft beer the international literature contains only a relatively small number of contributions. Existing studies have focussed on entrepreneurs and micro-breweries in the United Kingdom (Danson et al., 2015; Ellis \& Bosworth, 2015), USA (Alonso, 2011), Italy (Cannatelli et al., 2019), Sweden (Frisk \& Johansson, 2018) and Australia (Watne et al., 2012; Watne \& Hakala, 2013; Alonso \& Alexander, 2017). Home brewing, the production of fermented beverages for (mostly) non-commercial purposes, is a hobby which is viewed as a seedbed or generator of business start-up intentions for craft breweries and microbreweries (Biraglia \& Kadile, 2017). Researchers have disclosed the multi-faceted nature of home brewing as combining tangible elements such as the manufacture of craft beer, and the intangible such as the significance of sharing and socialising (Alonso et al., 2018). Explorations of home brewer motivational factors reveal that they engage and continue to participate in the activity "primarily because of intrinsic motivational factors of fun, excitement and enjoyment, and to a lesser degree by extrinsic motivational factors of learning opportunities and non-monetary savings" (Olson et al., 2014: 228). In a landmark examination of a nascent community of micro-brewing entrepreneurs in the US state of Alabama Alonso (2011) isolated several reasons for them opting to brew craft beer commercially. Among different motives were those of the discovery of business opportunities in terms of the niche market of craft beer, a change of professional focus in 
terms of a career change to the brewing of craft beer and a "desire to provide local consumers with a different yet more personalised beer product" (Alonso, 2011: 422).

In several investigations the transition of a hobby into a business is explained by the entrepreneurs' desire to share their passion for craft beer (Watne et al., 2012; Watne \& Hakala, 2013; Alonso \& Alexander, 2017; Frisk \& Johannsson, 2018). The concept of 'entrepreneurial passion' is defined by Cardon et al. (2009: 515) as "consciously accessible intense positive feelings experienced by engagement in entrepreneurial activities associated with roles that are meaningful for the self-identity of the entrepreneur". In Alabama Alonso (2011: 422) reported that all entrepreneur respondents "were in agreement that passion was the driving force behind their decision to open a micro-brewery". Frisk \& Johansson (2018: 40) explore the motivations for business start-up of craft brewers in Sweden and stress "it was their passion for the craft and the product that motivated them to start their companies". In another study conducted in Australia once again passion for the industry and hobby of craft brewing emerged as a driving force for new start-ups (Alonso \& Alexander, 2017). The multiple challenges of entrepreneurship in micro-brewing are highlighted in the UK context both by Danson et al. (2015) and Ellis \& Bosworth (2015).

Passion for the product can mobilize the needed energy for prospective entrepreneurs to overcome challenging situations by dealing with any uncertainties and setbacks in the gathering of financial, human and social resources (Biraglia \& Kadile, 2017; Cannatelli et al., 2019). Often entrepreneurial passion is associated also with 'creativity' as an important personal factor which is linked to the identification of opportunities that result in the establishment of new firms, including in the craft beer sector (Biraglia \& Kadile, 2017; Reid \& Gattrell, 2017). In Victoria, Australia Watne et al. (2012) identify how the region's craft brewing entrepreneurs were driven by some form of entrepreneurial passion and of how different forms of passion influence the business models that certain craft brewers choose to operate. Finally, from Sweden there is evidence that whilst the primary objective for why craft entrepreneurs started and maintained their microbreweries was because of passion it was observed that they perceived the achievement of profits as a necessity that would enable them the obtain their primary objective (Frisk \& Johansson, 2018).

\section{CRAFT BEER ENTREPRENEURS IN SOUTH AFRICA}

The South African material is organised in terms of three uneven sub-sections of material. These relate respectively to (1) study methods and sources; (2) industry development and geography; (3) a profile of craft beer entrepreneurs, their business motivations and start-up challenges.

\section{MATERIALS AND METHODS}

The empirical work on South Africa draws from a national audit of producers which derived from an examination of the local industry press (especially the journal On Tap) as well as an internet search of craft beer websites. Primary data on craft beer production and entrepreneurs was gathered by a combination of face-to-face surveys, telephonic interviews, an online survey and visits to craft breweries. In total interview responses were obtained from 53 craft breweries which for year 2016 represents nearly 28 percent of all licensed microbreweries in South Africa. Prior to the collection of data interview questions were tested to determine the validity, accuracy and time needed to complete the face-to-face and telephonic interviews. In addition to these interviews further semistructured interviews were undertaken with non-licensed microbrewers (essentially homebrewers) by attendance at the monthly meetings of 'Wart hogs', a homebrewers club in Johannesburg. In the presentation of qualitative material for ethical reasons only the names of craft breweries rather than of individual craft brew entrepreneurs are provided. 


\section{RESULTS AND DISCUSSION}

\section{Industry Development and Geography}

South Africa's first craft micro-brewery - Mitchell's Brewery at Knysna - launched operations in 1983 (Sidubi, 2017). Looking at the international historical spread of the craft beer revolution the beginnings of craft beer production in South Africa are similar to Australia (1980) and The Netherlands (1981) and preceded that of Italy's first brewpub in 1988 (Garavaglia \& Swinnen, 2017a). As happened in other countries, however, the momentum of subsequent growth was slow. Notwithstanding the dominance of the South African beer industry by the products of South African Breweries Ltd (SAB) only a trickle of new craft beer establishments occurred in the 1990 s and following South Africa's democratic transition in 1994. By 2003 a total of nine micro-breweries were in business. Acceleration in new brewery openings occurred post-2008 and especially during the period 2013 to 2016 which is the peak growth recorded for new start-ups of microbreweries in South Africa (Rogerson, 2016). By 2016 a national audit discloses a population of 187 (licensed) craft micro-breweries which are the foundation for the country's expanding contemporary economy of craft beer tourism (Rogerson \& Collins, 2015a).

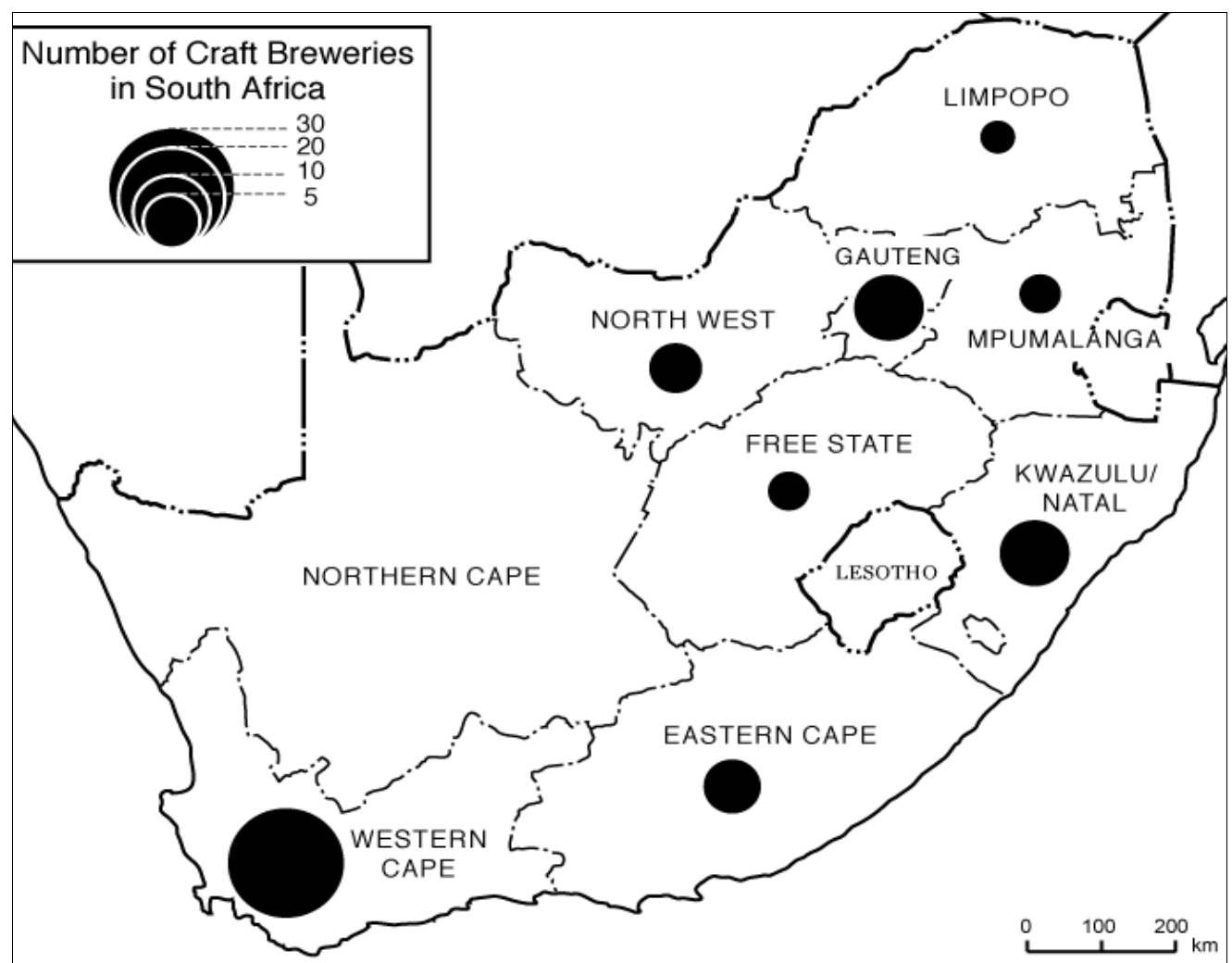

Figure 1. The Geographical Distribution of Craft Breweries in South Africa by Provinces

Figure 1 shows the broad geographical distribution of craft breweries across the country as disaggregated on a provincial basis (2013). It reveals a widespread growth of micro-breweries across the country. The largest numbers of craft breweries have been initiated by entrepreneurs in the Western Cape, Gauteng and KwaZulu-Natal which contain the country's large population centres. Of significance, however, is the strong 
clustering which occurs of craft breweries in some of South Africa's major tourism destinations such as Cape Town and Stellenbosch in the Winelands of Western Cape province. This result underscores the close relationship between entrepreneurship in craft brewing in South Africa and the country's growing tourism economy. Several craft breweries are situated in important small-town tourism destinations such as Clarens in Free State or Hermanus in Western Cape province (Rogerson, 2016; Rogerson \& Rogerson, 2019). The responses from craft beer entrepreneurs in Stellenbosch show the nexus of craft beer and the area's expanding tourism economy as a whole and with culinary tourism in particular: "From a tourism perspective we are located on one of the busiest roads between Paarl and Stellenbosch and it gives us access to the very popular 'Cape Spice Route' which has begun attracting many tourists to the region” (Interview, Sir Thomas Brewery). Another response from a Stellenbosch interviewee confirms the link between tourism and craft brewing entrepreneurship:

"The original vision for operating the microbrewery out of Stellenbosch is because it already has a big tourism market and we wanted to try draw upon some of the beer travellers which as you know globally - beer tourism is much bigger outside of South Africa... Stellenbosch has a big culinary following and association - I mean currently at the moment four out of the top ten restaurants in South Africa are found here and people love wining and dining which is great because it creates a trend and people become more open to new types of tastes, especially for example food and craft beer pairing" (Interview, Stellenbrau Brewery).

\section{Craft Beer Entrepreneurs - Profile, Motivations and Start-Up Challenges}

This section provides a descriptive overview of the key findings from the 53 interviews which were undertaken with microbrewing entrepreneurs. In terms of the population of beer entrepreneurs the results reveal a majority dominance of males who represented 92 percent of the sample. The age range of entrepreneurs operating microbreweries was between 26 and 73 years, albeit the largest group were in the range of 41 to 50 years. Two-thirds of entrepreneurs in the sample were over forty years old with average age of the sample being 44 years. A significant finding relates to the high level of education of these craft beer entrepreneurs. Of those respondents who provided information 81 percent had a university or technikon degree and almost 50 percent $(n=26)$ had obtained a post-graduate qualification.

The majority of the microbreweries would be categorised as family businesses. In total 64 percent of the respondents indicated that family members were involved in the running and operations of the microbrewery. Beyond family members, however, these craft micro-breweries are generating employment opportunities for an increasing number of people. Across the 53 survey enterprises the number of employees ranged from one to a maximum of 26 workers; the average across the sample was 4.8 employees. In total 73.6 percent of the sample engage five or less employees. The small-scale nature of these microbrewery operations is further evidenced by the production size of these microbreweries. Among the sample of respondents it was disclosed that the smallest production capacity was 10 ooo litres annually; the largest was just over five million litres. As a whole, half of the interview sample operated microbreweries which produced less than 50 ooo litres per annum. In terms of source of start-up capital the findings on Figure 2 confirm that microbrewery entrepreneurs use entrepreneurs' own savings or capital from their family as the core foundation for initiating the development of these microbreweries. In only a relative small number of cases was the business start-up funding sourced from external investors or through bank loans. 
The group of interviewees was dominated by entrepreneurs for whom the production of craft beer represented full-time work. Prior to establishing a microbrewery this group of well-educated entrepreneurs was involved in a variety of different forms of work. This included as professional chef, restaurateur, chemist, engineer, informational technology consultant, marketing, finance, advertising, education and farming.

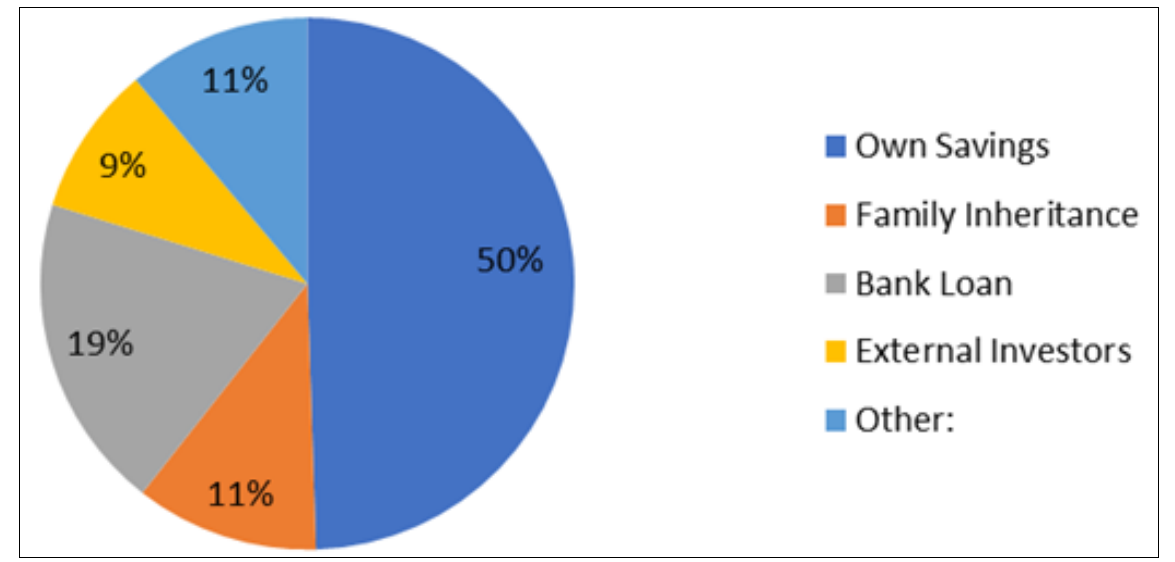

Figure 2. Source of Start-Up Capital Used by Craft Beer Entrepreneurs in South Africa

In several cases it must be noted there was a direct previous link to the established liquor industry. For example, one respondent was a former brand manager for SAB, another was an established winemaker, and a third had been involved in the distribution of craft beer from other existing micro-breweries. The differing routes into craft beer entrepreneurship in South Africa are illustrated by the following interview responses:

"Was setting up Paulaner Brauhaus Breweries around the world and then settled here in South Africa. But, overall 16 years Master brewer at Paulaner Brauhaus"

(Interview, Cape Brewing Company).

"I'm a restaurateur and basically saw the hype surrounding craft beer"

(Interview, That Brewing Company).

"I was employed as a winemaker" (Interview, Long Beach Brewery).

"I was running the chef school and still do but the microbrewery forms part of the chef school now” (Interview, Porcupine Quill Brewery).

"One of the partners worked and lived in San Francisco, and obviously being 'Beer Central' decided he wanted to start something when he returned to South Africa.... One of the other partners was already in winemaking and decided to come on board and give beer brewing a shot" (Interview, Devils Peak Brewery).

Of the sample of 53 respondents 83 percent stated that the brewery was a full-time business. The remainder indicated that work on the brewery was supplemented by other income-earning opportunities including 'consultancy work'. In three cases the microbrewery was regarded as a 'sideline' to running an existing winery.

One respondent elaborated as follows: "We were running an existing winery [Remhoogte Wine Estate] which is our primary business focus. We just started making beer for fun and then started selling a bit of it in our existing tasting room and it sort of snowballed from there on" (Interview, Wild Beast Brewery). In terms of the 
establishment of the microbrewery industry, the overwhelming emphasis in the interviews was that entrepreneurs started beer production as a hobbyist pursuit in terms of homebrewing then subsequently expanded it from a hobby by the recognition of a business opportunity. Overall, more than two-thirds of the respondents made it clear the microbrewery industry initially grew out of what was essentially a hobby, a finding that mirrors craft beer research in the USA (Alonso, 2011; Biraglia \& Kadile, 2017). The remainder of the sample were cases of the direct entry of entrepreneurs into the microbrewery industry because of a perceived business opportunity. The following interview responses exemplify these reasons for the establishment of microbreweries.

"A hobby which got out of hand a bit" (Interview, De Garve Brewery).

"A transition from a hobby - it had nothing financial to do with it; it was purely for the love and passion for brewing excellent beer" (Interview, Cape Brewing Company).

"Initially it was a hobby, then people really started enjoying our beer that we were making. We saw a good business opportunity from that stage to make a craft brewery in the heart of Durban North where none exists" (Interview, Odyssey Craft Brewery).

"Was initially a lifetime hobby of my father, and he decided to make a business out of it” (Interview, Black Horse Brewery).

"It was presented to us by a good friend and I have seen it as a business opportunity - farming is very hard these days" (Interview, Brauhaus am Damm).

"I think initially it started as a hobby, but the scale that we are at now we never planned or thought it would get so big so quickly, but obviously capital is a limiting factor. So, when we had enough capital to go bigger and to expand it we did it because we saw the demand and the growth in the sector" (Interview, Devils Peak Brewery).

"It was from a hobby, but it was not so much as me chasing it for a business opportunity - it was more me trying to get out of industry. You may have heard this story before but you go out and study after school you pick a career or a profession. You go into that and after a few years you get a bit disillusioned by the whole thing. It is more paper work and time consuming then it actually is thinking and designing stuff, so I wanted out. I looked at other opportunities and I loved my beer brewing - so I thought oh well, let's give it a shot and see if it works or not" (Interview, Basset Breweries).

In common with international research findings about the 'passionate' nature of entrepreneurs about microbrewing the overwhelming response from the sample of interviewees was the decision to enter commercial craft beer production linked to the entrepreneur's passion for beer. In only a small number of cases was there a recorded response that indicated that the entrepreneur was purely opportunistic. The following responses from the interviewees emphasize further the passion and lifestyle considerations that are directly linked to the production of craft beer in South Africa. Beyond simply lifestyle considerations many entrepreneurs recognized that their passion for producing craft beer could translate into a long-term business activity.

"Passion for beer and brewing. Wanting an alternative offering than mass commercial offerings for ourselves. Finding fans of our beers in friends and family alike also not wanting mass commercial beers" (Interview, Clarens Brewery).

"It seemed like something interesting to do! Why must we be forced to drink the same beer over and over again? I also don't like the idea of working for others and much prefer to be my own boss and fortunate enough right now that is a reality" (Interview, Odyssey Craft Brewery). 
"It's a lifestyle and passion choice. It was also strongly driven by our drive to become entrepreneurs and independent" and "Passion for the industry, and determination to own our own business" (Interview, Red Sky Brew).

"Love of beer and brewing, helping people see there is more to beer than just [SAB] Castle Lite" (Interview, Three Skulls Brew Works).

As a whole, these findings from South Africa align closely to those reported from other investigations particularly those in Australia, Sweden and the USA concerning business start-up and entrepreneurial motivations (cf. Alonso, 2011; Watne et al., 2012; Alonso \& Alexander, 2017; Frisk \& Johansson, 2018). Arguably, the craft beer economy of South Africa has been entered by a mass of entrepreneurs with a passion for the product, for the industry and to take up opportunities to untap a niche market. In many cases also professional/career and/or lifestyle change was another significant driver for craft beer business start-up. Further responses stressed the desire to launch a new business venture as well as the significance of identifying business opportunities in a local beer market landscape which was dominated by the products of large enterprises and especially of the homogeneous offerings of South African Breweries.

Respondents were queried as to the major challenges that they faced as start-up craft beer entrepreneurs. Several different themes emerged from the survey as well as the thematic analysis of the qualitative interviews. The two core issues related first to legislation and licensing considerations and second to establishing a market for their product. The question of the regulatory environment was an important focus in the interviews with craft beer entrepreneurs. From the responses of interviewees regarding the question 'What regulations they had to comply with in running a microbrewery and whether they may have encountered any issues with liquor licensing and/or zoning restrictions', the respondents raised a number of challenging issues about the regulation and licensing of start-up micro-breweries. These problems are evidenced in the following select comments from survey respondents.

"Three liquor licenses were needed, and yes it was a massive effort needed to get brewing license, the rest were health inspections for setting up of a kitchen" (Interview, Chameleon Brewhouse).

"There is a massive problem in Gauteng with obtaining licences" (Interview, Aces Brew Worx).

"As we are on a farm, we had to rezone the buildings. This took 4 years. Had to get a number of reports drafted for various government organizations - Water Affairs, Environmental Affairs, Roads Management, etc. The provisional liquor license took 1 year to come through" (Interview, Honingklip Brewery, Bot River).

"The Liquor Licence was a long road we basically waited a year for it, so each province has its own Liquor Board but the Natal one I think is just a little backwards. Otherwise zoning not a problem" (Interview, That Brewing Company).

"Oh yeah, the liquor licence was the main thing that held us back - unfortunately our government is not the quickest when it comes to these types of applications and our experience was absolutely horrible and we basically waited a year and six months for ours to be finally processed" (Interview, Sir Thomas Brewery).

A minority of respondents pointed out, however, that the issues relating to zoning and licensing were not major challenges in certain locations.

"No, our location for the microbrewery was originally zoned as an industrial area - and we planned accordingly prior to our launch so we never really encountered any major setbacks..." (Interview, Stellenbrau Brewery). 
"For me there were no obstructions, but I do know of a number of brewers who have encountered serious problems, whereby it took some of them two years to receive their licence...” (Interview, Triggerfish Brewery).

The establishment of a market for their craft beer production was a second obvious critical challenge for the successful establishment of these enterprises. The expansion of these microbrewery businesses is driven by internal processes for strategic marketing and selling of craft beer products. Across the sample of 53 craft breweries different methods for selling their craft beer product are observed (Figure 3). The findings reinforce the link between craft beer entrepreneurship and tourism. It is observed that the most important methods of sale were direct sales at the brewery which was used by 81 percent of the sample and participation at the increasing number of beer festivals which have proliferated across South Africa (Rogerson \& Collins, 2015b, 2015c). Other important sales were made through local brew pubs and restaurants as well as retail outlets.

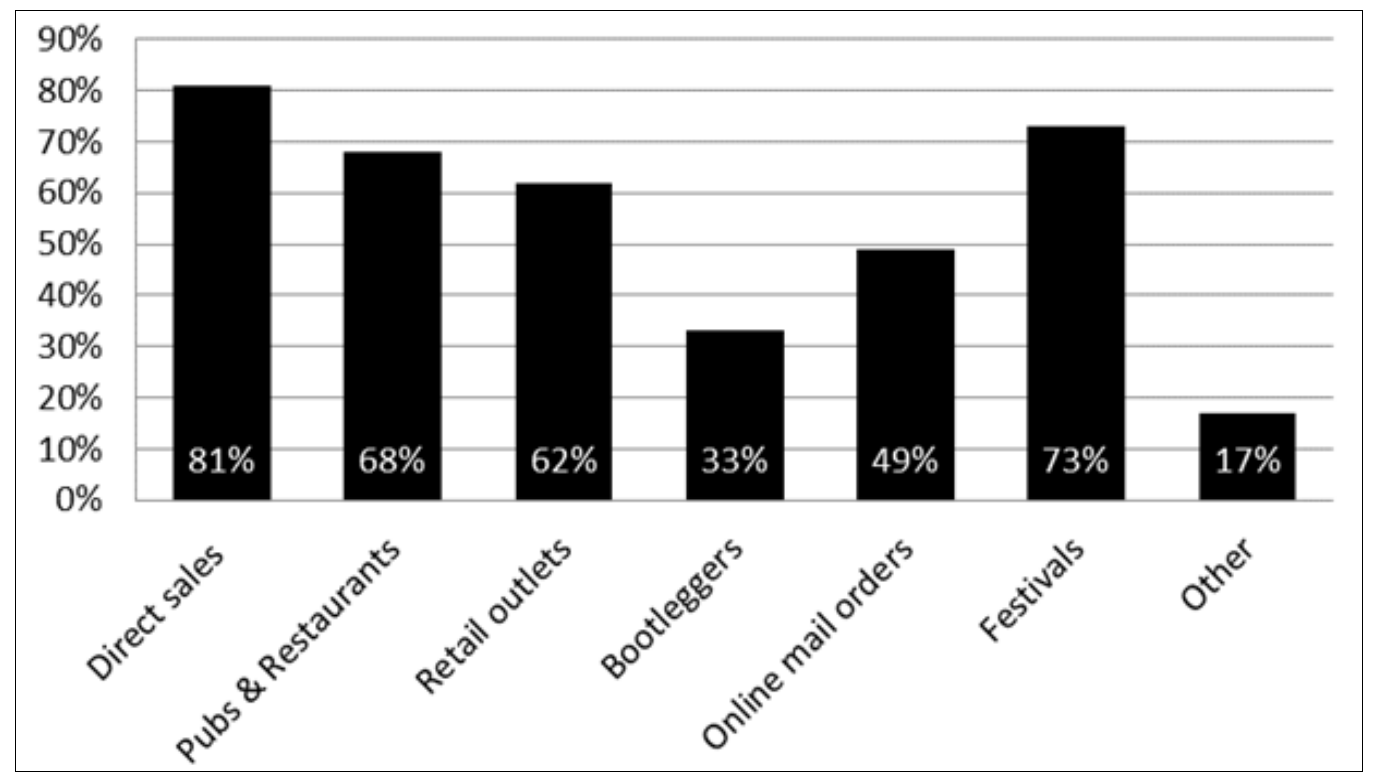

Figure 3. Different Microbrewery Sales Channels

The role of craft beer festivals was identified as especially important for marketing purposes. In total 83 percent of the sample rated craft beer festivals as either "important" or "very important" for business development. Indeed, the interviews revealed that craft beer festivals were a significant base for showcasing the craft beer products, for networking and provided a platform to interact with clients by allowing them to taste as well as to increase the awareness of the microbrewery in terms of its location and product offerings. Questioned as to how the microbrewery entrepreneurs market their beer, the role of craft beer festivals alongside that of social media was identified by 73.5 percent of the sample respondents. Equally of note was the significance of the internet and websites for marketing, which was used by more than two-thirds of the sample 64 percent. By contrast, traditional marketing channels of print magazines and newspapers were used by only 41 percent of the sample.

For small enterprises such as these microbreweries, of critical importance for business growth is the development of co-operative business relationships. In Canada 
Plummer et al. (2005) recognised that craft breweries tend to benefit from partnering and collaborating with one another. Similar results emerge from South Africa.

It was made clear that majority of microbreweries ( 85 percent) are involved in a variety of business relationships with other breweries in a manner that they co-operate together in order to increase their competitiveness. Important forms of co-operation relate to knowledge transfer, sharing of brewing ideas and collaboration in terms of technical support. In addition, of importance was the development of co-operative relationships regarding bulk buying of raw materials which reduces costs.

Further co-operation exists in terms of the distribution of products as well as cooperative marketing. The collective response from interviewees indicated that these microbrewery enterprises are expanding at a rapid rate due to changing market demands in South Africa. The reasons given for the expansion of these microbreweries were various and related to good branding, participation at craft beer festivals and the high quality as well as range of their beer product offerings.

"Absolutely, I put my growth down to good marketing and national visibility by going to every festival around the country” (Interview, Three Skulls Brew Works).

"I would say the main thing is that people want to try something new, they are tired of being forced to only drink $S A B$ products as that is all that has been available. There is a massive interest in the brewing process and when the public comes to a microbrewery they get to speak to the brewer, speak in depth about the beer. It isn't just one massive way to make beer; it's almost as if craft beer has its own unique beer drinking culture. People want to try something new, something different, and in central Durban nothing has existed like this before" (Interview, Odyssey Craft Brewery).

"Beer festivals are the main source of business. Festivals with food, like Taste of Joburg have been instrumental in making people aware of the craft beer market" (Interview, The Dog and Fig Brewery).

"More people are becoming aware of the distinctiveness of the craft beer we make” (Interview, Honingklip Brewery).

"The main contributing factors is definitely the increased interest in boutique beers from people who would usually be considered as 'SAB Loyalists' their whole life but are now willing to pay a little extra for a much better tasting beer... We are also focusing a lot of our marketing towards the local community of Stellenbosch and creating truly local beers which give recognition to the town and give us a good homegrown following" (Interview, Stellenbrau Brewery).

"Yes, the main influencing factors would be the growth of craft beer in general as a whole - so basically this whole new/big phenomenon that people want something different. They desire more flavour from their beer and they also don't want the watered down; commercially made beer anymore. I mean look everybody does still drink the stuff but I think people want something more - More options not just basic 'Lagers' (Interview, CBC Brewery).

In reviewing these above qualitative responses within a comparative international context it is significant to observe similar issues are raised about business challenges at the start-up of craft breweries as reported from research conducted in the United Kingdom, USA and Australia. In particular, the role of the legal framework in the control of the production and selling of craft beverages is stressed especially in research in the USA (Williams, 2017; Kline et al., 2017). For the nascent craft beer entrepreneurs of the 
state of Alabama Alonso (2011: 426) records that in establishing their craft beer facilities among the main challenges "it was not surprising to notice that the hindrance of the current laws was once again underlined among participants".

\section{CONCLUSION}

Beer tourism is expanding in international popularity as a niche form of food and drink tourism (Bujdoso \& Szucs, 2012a; Hall \& Gossling, 2016). Arguably, the most rapid current developments around beer tourism concern craft beer and visits to craft beer micro-breweries, brew pubs or beer festivals (Dunn \& Wickham, 2016; Kline et al., 2017). Small-scale craft beer entrepreneurs are the foundation and anchor for the recent emergence of craft beer tourism in South Africa. These entrepreneurs in South Africa are part of the ongoing international craft beer revolution triggered by consumer reaction against the homogeneous offerings from large macro-brewers.

In a theoretical context their appearance can be aligned with debates around resource partitioning in mature industries. The most striking finding about the beer entrepreneurs in South Africa is around the passion they express both towards the authenticity of their product and the new industry that they are currently shaping. The growth of tourism practices such as brewery tours, tasting bars and craft beer festivals is part of the emergence of this craft beer sector in South Africa. Further research investigations are merited concerning the unfolding of craft beer entrepreneurs and tourism in South Africa as well as other parts of the global South.

\section{Acknowledgement}

Chris Rogerson thanks the University of Johannesburg for research support and Keagan Collins thanks the National Research Foundation, Pretoria for funding support. Both authors acknowledge significant inputs to the paper from Teddy, Skye and Dawn Norfolk.

\section{REFERENCES}

Alonso, A.D. (2011). Opportunities and Challenges in the Development of Micro-brewing and Beer Tourism: A Preliminary Study from Alabama. Tourism Planning and Development, 8 (4), 415-431.

Alonso, A.D. \& Alexander, N. (2017). Entrepreneurial Intentions in an Emerging Industry: An Exploratory Study. Journal for International Business and Entrepreneurship, 10 (4), 406-426.

Alonso, A.D. \& Sakellarios, N. (2017). The Potential for Craft Brewing Tourism Development in the United States: A Stakeholder View. Tourism Recreation Research, 42 (1), 96-107.

Alonso, A.D., Alexander, N. \& O'Brien, S. (2018). "Every Brew is a Challenge and Every Glass of Good Beer is an Achievement": Home Brewing and Serious Leisure. Leisure, 42 (1), 93-113.

Alonso, A.D., Sakellarios, N. \& Bressan, A. (2017). Stakeholders and Craft Beer Tourism Development. Tourism Analysis, 22 (1), 45-58.

Argent, N. (2018). Heading Down to the Local?: Australian Rural Development and the Evolving Spatiality of the Craft Beer Sector. Journal of Rural Studies, 61, 84-99.

Biraglia, A. \& Kadile, V. (2017). The Role of Entrepreneurial Passion and Creativity in Developing Entrepreneurial Intentions: Insights from American Homebrewers. Journal of Small Business Management, 55 (1), 170-188.

Bujdoso, Z. \& Szucs, C. (2012a). A New Way of Gastronomic Tourism: Beer Tourism. Acta Turistica Nova, 6 (1), 5-20.

Bujdoso, Z. \& Szucs, C. (2012b). Beer Tourism From Theory to Practice. Academica Turistica, 5 (1), $103-111$.

Cabras, I. \& Higgins, D.M. (2016). Beer, Brewing, and Business History. Business History, 58 (5), $609-624$.

Campbell, S. \& Goldstein, R. (2010). The Beer Trials. New York: Fearless Critic Media.

Cannatelli, B., Pedrini, M. \& Braun, M. (2019). Individual-Level Antecedents of the Entrepreneurial Approach: The Role of Different Types of Passion in the Italian Craft Brewing Industry. International Entrepreneurship and Management Journal. https://doi.org/10.1007/s11365-019-00585-6

Cardon, M.S., Wincent, J., Singh, J. \& Drnovsek, M. (2009). The Nature and Experience of Entrepreneurial Passion. Academy of Management Review, 34 (3), 511-32.

Carroll, G.R. \& Swaminathan, A. (2000). Why the Microbrewery Movement?: Organizational Dynamics of Resource Partitioning in the U.S. Brewing Industry. American Journal of Sociology, 106 (3), 715-762. 
Carroll, G.R., Dobrev, S.D. \& Swaminathan, A. (2002). Organizational Processes of Resource Partitioning. Research in Organizational Behaviour, 24, 1-40.

Chapman, N.G. (2015). Craft Beer in the US: A Production of Culture Perspective. PhD dissertation, Virginia Polytechnic Institute, Blacksburg, Virginia.

Csapo, J. \& Wentzl, V. (2016). Possibilities for the Creation of Beer Routes in Hungary: A Methodological and Practical Perspective. European Countryside, 3, 250-262.

Danson, M., Galloway, L., Cabras, I. \& Beatty, T. (2015). Microbrewing and Entrepreneurship: The Origins, Development and Integration of Real Ale Breweries in the UK. Entrepreneurship and Innovation, 16 (2), 135-144.

Dunn, A. \& Kregor, G.M. (2014) Making Love in a Canoe No Longer?: Tourism and the Emergence of the Craft Beer Movement in California. CAUTHE Conference Paper, Proceedings Tourism and Hospitality in the Contemporary World: Trends, Changes and Complexity, 10-13 February, Brisbane, 190-198.

Dunn, A. \& Wickham, M. (2016). Craft Brewery Tourism Best-Practices: A Research Agenda. Annals of Tourism Research, 56, 140-142.

Ellis, V. \& Bosworth, G. (2015). Supporting Rural Entrepreneurship in the UK Microbrewery Sector. British Food Journal, 117 (11), 2724-2738.

Elzinga, K.G., Tremblay, C.H. \& Tremblay, V. (2015). Craft Beer in the United States: History, Numbers and Geography. Journal of Wine Economics, 10 (3), 242-274.

Esposti, R., Fastigi, M. \& Vigano, E. (2017). Italian Craft Beer Revolution: Do Spatial Factors Matter? Journal of Small Business and Enterprise Development, 24 (3), 503-527.

Francioni, J.L. (2012). Beer Tourism: A Visitor and Motivational Profile for North Carolina Craft Breweries. MSc thesis, University of North Carolina, Greensboro.

Frisk, C. \& Johansson, A. (2018). Passion Driven Companies in a Profit Driven Industry: A Qualitative Study on How Craft Entrepreneurs' Motivations Affect Their Perception of Competitive Strategy. Umea: Umea University.

Garavaglia, C. (2015). Entrepreneurship and Entry of Small Firms into a Mature Industry: The Case of Microbreweries in Italy. New York: American Association of Wine Economics Working Paper No. 179.

Garavaglia, C. \& Swinnen, J. (2017a). The Craft Beer Revolution: An International Perspective. Choices, 32 (3), 1-8.

Garavaglia, C. \& Swinnen, J. (2017b). Economic Perspectives on Craft Beer: A Revolution in the Global Beer Industry. London: Palgrave Macmillan.

Gomez-Corona, C., Escalona-Buendia, Garcia, M., Chollet, S. \& Valentin, D. (2016). Craft vs. Industrial: Habits, Attitudes and Motivations Towards Craft Beer Consumption in Mexico. Appetite, 96 (1), 358-367.

Hall, C.M. \& Gössling, S. eds. (2016). Food Tourism and Regional Development: Networks, Products and Trajectories. New York: Routledge.

Herrera, A.J. (2016). Craft Beer Expansion in the United States. Research Thesis, Claremont CA: Claremont McKenna College Paper 1279.

Howlett, S. (2013). Bureaus and Beer: Promoting Brewery Tourism in Colorado. Master of Science in Hotel Administration/Business Administration Management Dissertation, University of Nevada, Las Vegas.

Jablonska, J., Pobis, T. \& Timcak, G.M. (2013). Beer Tourism in Slovakia. In Geotour and Irse 2013 Conference Proceedings 25-27 September: Strategies of Building Geotourist and Geoheritage Attractions. Wroclaw and Zloty Stok: KGHM Cuprum Ltd Research and Development Centre, Technical University of Kosice, University of Miskolc, 67-74.

Kline, C., Slocum, S.L. \& Cavaliere, C.T. eds. (2017). Craft Beverages and Tourism, Volume 1: The Rise of Breweries and Distilleries in the United States. Cham: Palgrave-Macmillan.

Kraftchick, J.F., Byrd, E.T., Canziani, B. \& Gladwell, N.J. (2014). Understanding Beer Tourist Motivation. Tourism Management Perspectives, 21, 41-47.

Liu, M. \& Wezel, F.C. (2015). Davids Against Goliath?: Collective Identities and the Market Success of Peripheral Organizations During Resource Partitioning. Organization Science, 26 (1), 293-309.

Lyons, H. \& Sharples, L. (2008). Beer Festivals: A Case Study Approach. In C.M. Hall \& L. Sharples (eds), Food and Wine Festivals and Events Around the World: Development, Management and Markets. Amsterdam: Elsevier, 166-177.

Maye, D. (2012). Real Ale Microbrewing and Relations of Trust: A Commodity Chain Perspective. Tijdschrift voor Economische en Sociale Geografie, 103, 473-486.

McMullin, C., Bradley, M.J. \& Maples, J. (2019). Beer Tourism in Kentucky. Kentucky Journal of Undergraduate Scholarship, 3 (1), 40-46.

Murray, A. \& Kline, C. (2015). Rural Tourism and The Craft Beer Experience: Factors Influencing Brand Loyalty in Rural North Carolina, USA. Journal of Sustainable Tourism, 23 (8-9), 1198-1216.

Murray, D.W. \& O’Neill, M.A. (2012). Craft Beer: Penetrating a Niche Market. British Food Journal, 114 (7), 899-909.

Niester, J.G.A. (2008). Beer, Tourism and Regional Identity: Relationships Between Beer and Tourism in Yorkshire, England. Masters of Applied Environmental Sciences Thesis, University of Waterloo, Canada. 
Olson, E.D., Murphy, K.S. \& Ro, H. (2014). An Exploratory Study of Home Brewers' Motivational Factors. Journal of Foodservice Business Research, 17 (3), 228-241.

Patterson, M.W., \& Hoalst-Pullen, N. (2014). Geographies of Beer. In M. Patterson \& N. Hoalst-Pullen (Eds.), The Geography of Beer. Dordrecht: Springer, 1-5.

Pechlaner, H., Raich, F. \& Fischer, E. (2009). The Role of Tourism Organizations in Location Management: The Case of Beer Tourism in Bavaria. Tourism Review, 64 (2), 28-40.

Plummer, R., Telfer, D., Hashimoto, A. \& Summers, R. (2005). Beer Tourism in Canada Along the WaterlooWellington Ale Trail. Tourism Management, 26 (3), 447-458.

Poelmans, E. \& Swinnen, J.F.M. (2011). From Monasteries to Multinationals (and Back): A Historical Review of the Beer Economy. Leuven, Belgium, LICOS Discussion Paper Series 294/2011.

Pozner, J-E., DeSoucey, M. \& Sikavica, K. (2015). Bottle Revolution: Constructing Consumer and Producer Identities in the Craft Beer Industry. Berkeley: University of California Institute for Research on Labor and Employment Working Paper No. 108-15.

Reid, N. \& Gattrell, J.D. (2017). Creativity, Community \& Growth: A Social Geography of Urban Craft Beer. Region, 4 (1), 31-49.

Rogerson, C.M. (2016). Craft Beer, Tourism and Local Development in South Africa. In C.M. Hall \& S. Gössling (Eds.), Food Tourism and Regional Development: Networks, Products and Trajectories. New York: Routledge, 227-241.

Rogerson, C.M. \& Collins, K.J.E. (2015a). Beer Tourism in South Africa: Emergence and Contemporary Directions. Nordic Journal of African Studies, 24 (3-4), 241-258

Rogerson, C.M. \& Collins, K.J.E. (2015b). Developing Beer Tourism in South Africa: International Perspectives. African Journal of Hospitality, Tourism and Leisure, 4 (1), 1-15.

Rogerson, C.M. \& Collins, K.J.E. (2015c). Festival Tourism in South Africa: Characteristics and Motivations of Attendees at Craft Beer Festivals. African Journal for Physical, Health Education, Recreation and Dance, 21 (Supplement 1), 76-87.

Rogerson, C.M. \& Rogerson, J.M. (2019). Tourism, Local Economic Development and Inclusion: Evidence from Overstrand Local Municipality, South Africa. GeoJournal of Tourism and Geosites, 25 (2), 293-308.

Sidubi, F. (2017). Mitchell's Brewery: Challenges and Opportunities Faced by a Small-Medium Enterprise Entrepreneur/Venture in a Growing Sector in South Africa. Masters of Administration Research Report, The Graduate School of Business, University of Cape Town.

Slocum, S.L. (2016). Understanding Tourism Support for a Craft Beer Trail: The Case of Loudoun County, Virginia. Tourism Planning \& Development, 13 (3), 292-309.

Slocum, S.L., Klein, C. \& Cavaliere, C.T. eds. (2018). Craft Beverages and Tourism, Volume 2: Environmental, Societal and Marketing Implications. Cham: Palgrave-Macmillan.

Toro-Gonzalez, D. (2015). The Beer Industry in Latin America. New York: American Association of Wine Economics Working Paper No. 177.

Tremblay, V.J., Iwasaki, N. \& Tremblay, C.H. (2005). The Dynamics of Industry Concentration in the US Micro and Macro Brewers. Review of Industrial Organization, 26 (3), 307-324.

Watne, T. \& Hakala, H. (2013). Inventor, Founder or Developer?: An Enquiry into the Passion that Drives Craft Breweries in Victoria, Australia, Journal of Marketing Development and Competitiveness, 7(3), 54-67.

Watne, T., Kautonen, T. \& Hakala, H. (2012). Business from Passion?: An Enquiry into the Business Models of Craft Breweries in Victoria, Australia. Proceedings International Council for Small Business World Conference (ICSB), Wellington, New Zealand, 10-13 June.

Williams, A. (2017). Exploring the Impact of Legislation on the Development of Craft Beer. Beverages 3, 18; doi: 10.3390/beverages3020018.

Submitted:

27.08.2019
Revised:

03.12.2019
Accepted and published online 05.02.2019 